\title{
From Crisis to Nationalism?
}

\section{The Conditioned Effects of the COVID-19 Crisis on Neo-nationalism in Europe}

\section{Zhongyuan Wang ${ }^{1}$}

Received: 25 July 2020 / Accepted: 12 November 2020 / Published online: 4 January 2021

(c) Fudan University 2021

\begin{abstract}
Will nationalism thrive in times of crisis? A broad segment of scholarly literature has found that a crisis often leads to the resurgence of nationalism. When the coronavirus started to spread rapidly in Europe, individual European nation states unilaterally closed their borders, hoarded critical medical supplies, and played blame games. The early period of the pandemic crisis revealed some hybrid form of medical nationalism, economic nationalism, and everyday nationalism. However, the common crisis has also heightened the importance of regional solidarity, and reinforces a strengthening of cross-national cooperation and multilateral institutions. Based on empirical discussions, this research offers an analytical framework to establish the hypothetic mechanisms of understanding this mixed phenomenon. Delving into the interaction between crisis and nationalism, this article argues that the causation from one to the other is not a linear, one-way process. There are competing mechanisms through which both nationalists and liberalists can use the crisis to push for their political agenda. Whether there will be a new wave of neo-nationalism in Europe is largely contingent on the responses the EU and the member states adopt in handling domestic and regional challenges in the post-pandemic era. Therefore, instead of simply exploring the causal relation between crisis and nationalism, more-nuanced questions can be examined in the future concerning the conditions under which and the mechanisms through which a crisis is more/less likely to provoke neo-nationalism.
\end{abstract}

Keywords COVID-19 pandemic $\cdot$ Nationalism $\cdot$ Europe $\cdot$ Far-right parties

Paper submitted to the CPSR special issue on "COVID-19 and New Scenarios in Europe".

Zhongyuan Wang

wangzy@fudan.edu.cn

1 Fudan Institute for Advanced Study in Social Sciences, Fudan University, Shanghai, China 


\section{Introduction}

Will nationalism thrive in times of crisis? Over the past years, many European countries have witnessed rising nationalism, which was largely driven by the Euro-zone economic crisis and the refugee crisis. Far-right political parties and nationalist candidates have gained significant influence in subnational elections, national-level elections, and EU parliamentary elections. It is visible from France, where Marine LePen of the National Front won 33.9\% votes in the second round of presidential elections in 2017, to the Netherlands, where the Freedom Party has become the biggest opposition party in the parliament, and to Italy, where the far-right League Party gained a foothold in a populist ruling coalition in the government. These nationalist forces have been able to shape and reshape state policies as well as the European agenda by either taking positions in the parliament and coalition government. More importantly, these developments have triggered what Sartori earlier labeled as "polarized pluralism" - a process where mainstream moderate views are gradually radicalized and replaced by polarized views (Sartori 1966). Moreover, at the European level, ten far-right parties in the European Parliament have launched a new political bloc, called Identity and Democracy (ID), with the mission to resist immigration, increase security, and fight EU bureaucracy. In recent years, nationalist parties and politicians across Europe have found a common voice and have learned to strategically capitalize on every single possible crisis to tap into voters' frustration with the political establishment, concerns about immigration and security, and skepticism about globalization and Europeanization. The outbreak and spread of the COVID-19 pandemic, a novel global public health crisis in 2020, seem to have added new fuel to exacerbate nationalism in Europe. Will there then be a new wave of nationalism? And why or why not? If so, what makes the coronavirus crisis unique in elevating various forms of neo-nationalism? Overall, this article looks at a popular and politicized topic (nationalism) through the lens of a topical issue (pandemic) to tease out the interactions and causations.

This research seeks to reevaluate the plausible causal relations between the pandemic crisis and rising nationalism in Europe, and to uncover the mixed results conditioned by responsive actions of the key players. It will adopt mechanism-based case studies to explore the neo-nationalist phenomenon in Europe amidst the pandemic. As a study aiming to provide a fresh analysis to prompt further debates, it mainly relies on descriptive evidence and second-hand data collected from multiple sources including government websites, scholarly works, news reports, think tanks reports, and international non-governmental organizations. The article will proceed in the following manner. The next section reviews the literature on nationalism and neo-nationalism in political science. The third section illustrates the shortterm symptoms of rising nationalism as a result of the pandemic crisis, including the surge in medical nationalism, economic nationalism, and everyday nationalism. A fourth section then identifies and analyzes the competing causal relations and 
mechanisms ${ }^{1}$ that transform crisis to nationalism or Europeanism, highlighting the conditioned effects of the COVID-19 crisis on neo-nationalism in Europe. In the concluding section, I will summarize the main arguments and postulate the broader implications and further research possibilities.

\section{From Nationalism to Neo-nationalism: The Role of Crisis}

Nationalism is a modern phenomenon. It has appeared since the establishment of modern national states, and is associated in complex ways with modernization, industrialization, globalization, social mobility, and political crisis. Nationalism has objective aspects in terms of physical, ethnic, and territorial characteristics that a group of citizens commonly share. Yet, it also contains subjective dimensions in terms of a common ideological belief and identity that are imaginatively constructed (Gilbert 1998; Miller 2008). Political scientists define nationalism in different ways, from distinct perspectives and on multiple levels. At the state level, nationalism is conceptualized as a form of state policy from top down to drive and advance the idea of independence and solidarity through means such as war, education, media, and language (Hechter 2000; Tilly 2001). At the group/community level, nationalism can be understood as a series of narratives and movements that are created to stir up a feeling of belonging to an inner group through shared ethnicity, traditions, memories, and symbols (Gellner 1983; Anderson 1991; Fabre and Cassia 2007). At the individual level, nationalism refers to sentiments and actions that are expressed by fellow nationals from bottom-up, either to make sense of their lives in the framework of supra-personal narrative (Miller 2008), or to sharpen the contrast against "the others" who are alien to their community. Furthermore, scholars have developed more than a dozen typologies to describe various forms of nationalism under different scenarios, including but not limited to ethnic nationalism, civic nationalism, cultural nationalism, religious nationalism, liberal nationalism, state-building nationalism, irredentist nationalism, peripheral nationalism, unification nationalism, inclusive nationalism, exclusive nationalism, etc. (Gledhill 2005; Hechter 2000). It seems almost impossible for researchers to reach an agreement upon a single cohesive definition of nationalism, but generally speaking, it emphasizes inward homogeneity and outward uniqueness.

As can be seen from above, although nationalism can be clearly distinguished from liberalism, its original idea is not necessarily irrational, extreme, and violent. David Miller has identified three basic elements of nationalism: the first element is simply the idea that a real nation exists which can differentiate its citizens from those who belong to other nations; the second element is emphasizing on the practical implications of national membership that entails rights and obligations, and the third element mainly refers to political independence and self-determination (Miller

\footnotetext{
1 Causal mechanism has a plethora of meanings. In this article, it mainly refers to the pathway or process by which a causal effect is produced in a given context. For methodological discussions on causal mechanism, see Tilly (2001), McAdam et al. (2008), Gerring (2010).
} 
1997, 2008). Therefore, nationalism constituted by different combinations of these three elements will present different features, instrumental functions, and political implications. On one hand, nationalism serves to bind people together and attach them to their national homeland. On the other hand, it creates indifference and is even likely to generate hostility towards outsiders (Miller 2008). The result could be radical, exclusive, and violent, while it could also be civic, inclusive, and peaceful. Theoretically, attempts have been made by some researchers to bridge the gulf between nationalism and liberalism through advocating a new brand of civil/liberal nationalism (Tamir 1993; Charney 2003). Practically, maintaining a civic and inclusive form of nationalism calls for stronger solidarity and better governance performance in times of multifold crisis. In general, the contents and consequences of nationalism are largely determined by how nation states, political elites, and citizens adopt the various elements of nationalism.

However, the unifying and benevolent effects of nationalism may only be possible to achieve under certain favorable political circumstances. In a world of many newly emerging political crises, the rise of extreme and exclusive elements of nationalism appears unavoidable. Since the end of the Second World War, a new extreme form of nationalism has grown out from classic nationalism, usually labeled as neo-nationalism or new nationalism, as a counter-movement to an intricate range of social, economic, and political transformations that accompanied regionalization, globalization, and bureaucratization. As a working definition, neo-nationalism is the reemergence of nationalism under the new global and transnational contexts and represents "new" forms of interactions with and reactions towards the fairly recent economic, political, and socio-cultural developments such as immigration, globalization, regionalization, and multiculturalism (Gingrich and Banks 2006, 2-7; Norris and Inglehart 2019). Neo-nationalism highlights the distinctions between the nationalistic ingroup and outgroup ("othering") and activates some irrational elements of nationalism. "Neo-nationalism is neither an isolated phenomenon, nor is it internally coherent" (Gingrich and Banks 2006, 3). Neo-nationalist attitudes, narratives, and actions are often closely associated with some narrow political ideologies or positions such as nativism, far-right populism, cultural separatism, anti-establishment, anti-globalization, anti-immigration, protectionism, xenophobia, and Euroscepticism (Mudde 2000; Ignazi 2003; Gingrich and Banks 2006). In recent years, neonationalism has become increasingly instrumental in today's electoral politics, as many political parties and populist politicians capitalize on it to shape citizens' voting behavior and political attitudes (Norris 2005; Givens 2005; Mudde 2007).

Europe has experienced several waves of rise of neo-nationalism in the postworld-war era. The growing pattern of new nationalism was greatly driven by the emergence of various economic and political crises over the years. Bergmann (2020) has identified three waves of nationalist sentiment and movement since the 1950s, with the anti-taxation (anti-big government) and anti-multiculturalism in the wake of the Oil Crisis in the 1970s representing the first wave of neo-nationalism, which generated nationalist movements and far-right parties in many European countries including France, Denmark, and Norway. The second wave of neo-nationalism was mainly triggered by the influx of immigrant workers from Eastern Europe after the fall down of the Berlin Wall in 1989. With the international financial crisis starting 
in 2008 came the third wave that has recently reached new heights during the refugee crisis. It can be easily observed that external shocks and crises constitute the primary source of neo-nationalism in contemporary Europe.

The causal mechanisms from crisis to nationalism are based on the process that political or economic shocks will push nationals to pin the blame on outsiders, take self-protectionist actions, develop nativist sentiments, and resort to anti-establishment movements. As a result, since the most recent refugee crisis, neo-nationalists have dominated much of the electoral agenda in most European countries and at the European level, which has led to frequent instances where far-right nationalist parties and candidates won parliamentary seats or established a formal footing in the coalition government. On other occasions, nationalist forces, although suffering limited electoral gains, can still radicalize mainstream parties and pressure them to adopt more nationalist stances as they struggle to secure their electoral base (Mudde 2016).

Against this background, the novel coronavirus crisis of 2020 seems to have again provided an extended fertile ground for another wave of neo-nationalism in Europe. More specifically, since many Europeans tend to consider the pandemic as a result of globalization, regionalization, and immigration that has turned their health situations, daily lives, and economic conditions upside down, neo-nationalist sentiments and actions can therefore be more easily generated and evoked among the public amid the coronavirus crisis. This is especially when far-right populist politicians tried to capitalize on the crisis to promulgate the discourse of "othering" and push for protectionist and nativist policies. All these will likely facilitate the fourth wave of neo-nationalism.

\section{The Fourth Wave of Neo-nationalism?}

The COVID-19 pandemic represents a huge health and safety crisis to all people around the world. Since the disease was first confirmed in Italy in late January, the coronavirus has been spreading rapidly and aggressively in Europe. European countries' initially slow response to the outbreak caused the continent to become the planet's coronavirus hot zone. On 13 March 2020, as the number of new reported cases surpassed those in China and doubled every several days, the World Health Organization (WHO) classified Europe as the new "epicenter" of coronavirus pandemic. According to the data collected by the European Centre for Disease Prevention and Control (ECDC), as of 11 July 2020, 1,578,229 cases (about 15\% of all world cases) of coronavirus disease have been reported in the EU countries and the UK, including 179,168 deaths (about 35\% of all world deaths). Although the number of reported cases and the mortality rate vary in European countries, the COVID19 pandemic is posing an unprecedented threat to the European Union and all EU member states.

During the coronavirus pandemic, national borders were closed, restrictions on nonessential movements were imposed, a state of emergency in many countries was introduced, millions of people were in lockdown, and people are facing various challenges in their work activities and daily lives. Just like the pandemic has greatly 
changed the fabric of life, it also shows the potential to transform European politics in profound ways. One of the concerns is the resurgence of neo-nationalism during the time of crisis. As Stephen Walt wrote, "the pandemic will strengthen the state and reinforce nationalism. Governments of all types will adopt emergency measures to manage the crisis". ${ }^{2}$ Has the pandemic crisis exacerbated neo-nationalism in Europe? Various symptoms of rising nationalism have been observed in European countries over the past months, in terms of renewed nationalist responses in the form of medical nationalism, everyday nationalism, and economic nationalism.

\subsection{Medical Nationalism}

As the global pandemic spreads, the demand for life-saving medical supplies to fight the pandemic is unprecedented. In responding to the escalating public health crisis, a large number of European countries were spontaneously pursuing nationalistic policies. This involved taking a "my nation first" approach to compete against each other for essential health products and protective equipment, rather than working together to implement a Europe-wide coordinated strategy. As such, it escalated into a tide of "medical nationalism" in the early months of the COVID-19 outbreak, displaying a burgeoning spread of neo-nationalism that was already sweeping the European continent before the pandemic hit. Regional alliances have been fraying as a result of the growing uncertainties and fears.

Export protectionism has risen considerably since February as EU member states, one after another, moved to introduce trade prohibitions or restrictions on medical goods as a result of the COVID-19 pandemic. According to the Global Trade Alter, as of May 1, 27 European countries have taken at least 30 actions to impose temporary export restrictions of medical supplies and medicines. Key items on the list of export controls include face masks, protective clothing, medical equipment, ventilators, shoves, chemicals, sanitation products, and other badly needed medical supplies. For instance, early in the crisis when Italy was one of the countries to be badly hit and needed a helping hand from the EU and other member states, little medical help was extended to the Italians in those first weeks. Rather, many of its European neighbors were in rush to hunt for medical supplies and impose export controls as concern about the crisis was mounting. France has requisitioned stocks of FFP2-type masks in early March and further expanded its list of drugs covered by export restrictions in April. On March 4, Germany banned the export and intra-EU transfer of medical protection gear such as breathing masks, medical gloves, and protective suits to ensure local needs. For these European countries, the coronavirus is not merely a health crisis, but has also become "a question of national security," as German Interior Minister, Horst Seehofer, warned. National governments must

\footnotetext{
${ }^{2}$ Nicholas Burns Joseph S. Nye Stephen M. Walt, "How the World Will Look After the Coronavirus Pandemic", March 20, 2020; see https://www.belfercenter.org/publication/how-world-will-look-after -coronavirus-pandemic (Accessed on June 18, 2020).
} 
take responsibility, he emphasized, to ensure not only the security of their borders and their food supply, but also "our medical products and our medicines."3

Moreover, vaccine nationalism also has increasingly gained prominence as nation states are engaged in the chaotic race to manufacture and control coronavirus vaccines. Ideally, regional and global governance bodies should have more leverage to allocate and distribute the delivery of the COVID-19 vaccine when available, because "no one is safe until everyone is safe" amid this global pandemic. However, there is a widespread fear that the first country to successfully create the vaccine will likely impose export restrictions on it to ensure priority access for its local population. The distinction of self vs others can be highlighted and manipulated by national governments and politicians as people are desperate for scarce vaccine supplies amid the pandemic. In addition to medical goods, temporary-trade restrictions were even extended to some foodstuffs. This has resulted in nationalist calls to supply locals first and "eat patriotically", creating a new wave of food nationalism 4 in Europe. For example, France's Agriculture Minister declared "I am calling for food patriotism, for agricultural patriotism," encouraging citizens to buy French cheese, strawberries, and tomatoes over foreign ones, even though these products may be pricier. ${ }^{5}$ The Rural Economy Secretary of the UK endorsed the Scottish Government's campaign to support dairy farming, and claimed that "I would encourage everyone in Scotland who can take part to support local farming and food production." It is largely understandable that national states may resort to a unilateral and selfish agenda to mitigate potential shortages in key supplies and protect their people when they had no clear ideas or plans to cope with the unknown crisis. However, a scramble for national interests will highly likely escalate into neo-nationalism, providing political opportunities for nativist nationalists who favor greater protectionism and want to "take back control".

In classic political theory, nationhood is often considered as a precondition for personal security and social justice (Miller 1997, ch.4). Nation states are supposed to "provide every citizen with a certain level of protection against the contingencies of life" (Miller 2008). Therefore, there are some legal provisions enshrined in European treaties that permit such measures. However, when national governments insist on a protectionist approach, far-right nationalists will capitalize on this momentum

\footnotetext{
3 See "Corona virus: Interior Minister Horst Seehofer explains the border closures-domestic politics", available at https://www.corona24.news/c/2020/03/16/corona-virus-interior-minister-horst-seehofer-expla ins-the-border-closures-domestic-politics.html (Accessed September 9).

4 Food nationalism (also called "gastronationalism") is a world phenomenon, which involves various political issues including cultural identity, food security, and food protectionism. Europe has a long history of food nationalism, with some European countries suffering what can be called food peripheral nationalism (e.g., Spain, UK, or Italy). For related studies, see DeSoucey (2010) and Ichijo and Ranta (2016). During the pandemic, many European governments seized on the crisis to pressure citizens to eat local products with patriotism.

5 See Zosia Wanat and Eddy Wax (2020), "Coronavirus Reheats Europe's Food Nationalism", available at https://www.politico.com/news/2020/05/17/coronavirus-reheats-europes-food-nationalism-262251 (Accessed May 21).

${ }^{6}$ See "Dairy industry unites to launch $£ 1 \mathrm{~m}$ consumer campaign", available at https://ahdb.org.uk/news/ dairy-industry-unites-to-launch-1m-consumer-campaign (Accessed September 9).
} 
to advocate a form of "me first" nationalism that pits one nation against another in the pursuit of local interests and to protect their own nationals. This will further legitimize their radical proposals to close borders, deport immigrants, and turn away from international organizations, creating momentum toward neo-nationalism. Therefore, concerns have been raised regarding whether EU member states that recover from the pandemic will become more tribal, more narrowly minded, and more anti-regionalization.

To avoid ineffective nationalistic responses and prevent a new wave of neonationalism, the EU has called for regional solidarity by negotiating with member states to unblock export restrictions and mobilizing resources to help hot-spot countries. For instance, in an attempt to ensure that medical equipment continues to circulate within the EU, the European Commission, Germany, and France have negotiated to end the intra-European export restrictions on medical supplies. Italy and Spain have now received considerable medical assistance via the EU Civil Protection Mechanism and from several EU member states. For example, Germany sent 1 million face masks to Italy; Estonia also donated $€ 100,000$ and 30,000 masks to Italy. According to the information released by European Solidarity Tracker, Italy now has become one of the top beneficiaries of pan-European support. ${ }^{7}$ It is predicted that a more coordinated, trusted European-level governance system to ensure the appropriate flow of medical supplies and distributions will help mitigate the "pandemic of nationalism". Paradoxically, while the European Union tried to seek solidarity and had discouraged the member states from implementing restrictive measures in response to the crisis, it also introduced an EU-wide ban to limit exports of certain medical products to destinations outside the bloc, in a bid to keep sufficient supplies within the EU.

\subsection{Economic Nationalism}

The crisis of the COVID-19 pandemic and the lockdown policies taken to curb the virus spread present an unprecedented challenge to the world economy. The apparent lack of solidarity among EU member states during the early days of the crisis nearly brought Europe's single market to a standstill and fueled the rise of economic nationalism after Europe has already borne the brunt of the European debt crisis and immigration crisis for years. According to the data published by Eurostat, the EU's statistical office, the bloc suffered its sharpest decline in more than a decade since the 2008 financial crisis, with a decrease of the GDP by $3.6 \%$ in the Eurozone during the first quarter of $2020 .{ }^{8}$ Even worse, Europe is predicting a record fall in its GDP and drastically revised the unemployment rate upward this year as the disease continues to disrupt international trade and investment flows. However, the pandemic's economic impact across Europe has been asymmetric. Among the

\footnotetext{
7 See the website of European Solidarity Tracker set-up by the European Council on Foreign Relations, https://www.ecfr.eu/solidaritytracker (Accessed on June 22, 2020).

${ }^{8}$ For details, see https://ec.europa.eu/eurostat/documents/2995521/10294996/2-09062020-AP-EN.pdf/ (Accessed on June 22, 2020).
} 
member states for which data are available, the highest decline in GDP in Europe was experienced by France and Italy (both $-5.3 \%$ ) as well as by Spain and Slovakia (both $-5.2 \%$ ). How have European countries responded? At a time of growing protectionism, the COVID-19 tends to further push Europe toward a more nationalistic response economically.

The pandemic is a serious threat to the viability and integrity of the multilateral trading system. Many Europeanists are used to and appreciative of open borders and a single market. However, the coronavirus outbreak offers an excuse to close borders and end the freedom of movement - a longstanding demand of neo-nationalists. In early March, when Italy first became the epicenter of the outbreak, many European countries have reacted with protectionist measures. At least half of the Schengen States, in rapid succession, rushed to reintroduce border closures of some kind at their borders. As the disease continued to spread, more than a dozen of European countries, together with the bloc as a whole, have imposed travel bans and border controls. At the same time, many nationalist parties and politicians (including those of Hungary, Italy, and Poland) seized the opportunity presented by the pandemic scare to aggressively push their border-control agenda. To be sure, as an essential part of emergency governance, temporary restrictive measures on movement-internationally and within countries-are necessary to slow down the spread of the disease and effectively save lives. However, chaotic border closures in every-nation-foritself fashion may also undermine the economies and could severely disrupt the flow of trade and investment, especially for a previously borderless free-market zone. Moreover, it is accompanied by signs of a strong resurgence in protectionism. Some European countries have started to switch their industrial policies to place more emphasis on national self-sufficiency, safeguard strategically important industries against foreign take-over, and implement stronger screening of foreign investment. ${ }^{9}$ Such a move leads to a growing concern that the COVID-19 crisis may create a world that will be less open, less free, and less prosperous, reinforcing the existing trend towards the rise of economic nationalism in Europe and damaging the already fragile world economic system.

The coronavirus pandemic has also sparked a firestorm of nationalism in financial areas. To rescue the hardest-hit member states as well as to finance recovery from the economic recession, the EU proposed to use fiscal instruments of joint borrowing and debt-sharing. Calls were made for the creation of the so-called "corona bonds" which will mutualize risk across all Euro-zone members and organize them to share the burden of common debts. Such a plan, however, must gain unanimous backing of all 27-member states and needs to be approved by national leaders and their parliaments. A similar notion of "Eurobonds" had been previously raised during the 2008 financial crisis, but wealthier countries in northern Europe considered

\footnotetext{
${ }^{9}$ It is noteworthy that these protectionist trade and investment policies are mainly oriented to external investors (mostly China), but much less to the EU's single market. For related discussions, see Valentina Pop, 2020 "EU Moves to Shrink Chinese, U.S. Influence in Its Economy", available at: https://www.wsj. com/articles/eu-moves-to-shrink-chinese-u-s-influence-in-its-economy-11592393124 (Accessed September 10, 2020).
} 
collective debts to be unfair and therefore rejected the plan. This time, some countries again prioritized national concerns over a unified response even when the coronavirus has so fundamentally damaged the bloc's economy. This is in part caused by the very fact that the pandemic has disproportionately affected the European south much more than the continent's wealthy north. Consequently, disagreement emerged amid the deep North-South divide. Italy, Spain, Portugal, and Greece strongly demanded the common debt instrument, while Netherlands, Germany, Finland, and Austria were adamantly opposed to any kind of coronavirus-related debt mutualization. Both sides are facing various attacks by populist nationalist politicians at home. For instance, in Germany, Alternative for Deutschland (AfD), which is now the third-largest party in the German Parliament, has bluntly rejected the idea of corona bonds by saying that the coronavirus cannot "justify that German taxpayers are bled for the debt of the whole EU." "10 Although leaders of Germany and France have recently agreed to support the EU's pandemic recovery fund, there will still be some tough negotiations among EU member states and the potential for a lengthy approval process by individual countries. Since a joint debt will vest greater power and authority in the EU by giving it more of the semblance of a central government, ${ }^{11}$ such an EU-level recovery plan may further exacerbate the Eurosceptic nationalist politics. For example, in Italy, the League Party, the populist anti-EU far-right party, has launched an aggressive campaign against the proposal of Italy accepting money from the EU's crisis bonds.

Economic nationalism can be understood as economic activities that "are and should be subordinate to the goal of state building and the interests of the state" (Gilpin 1987: 31). The resurgence of economic nationalism was usually a product of economic crises, nationalist movements, and enlarged states (Pryke 2012). It often creates political hierarchy between "my nation" and other nations in the pursuance of national economic interests. In a more protectionist post-COVID environment, Europe will face a political-economic dilemma. On one hand, it has to scale up its efforts in adopting more ambitious financial measures to rescue and stimulate the regional economy. On the other hand, it must prepare to see the rise of Eurosceptic populism and nationalist movements caused by an empowered EU and the new common debts.

\subsection{Everyday Nationalism}

The crisis of the COVID-19 pandemic has also led to an increase in acts and displays of everyday nationalism in European countries. Everyday nationalism is a new approach to observe and study nationalism by focusing particularly on everyday

\footnotetext{
10 See Silvia Amaro, 2020, “Corona bonds': Here are three reasons why Germany and the Netherlands oppose the idea", available at: https://www.cnbc.com/2020/04/08/corona-bonds-reasons-why-germanyand-the-netherlands-oppose-the-idea.html (Accessed September 12, 2020).

11 Douglas A. Rediker and Giovanna De Maio, "Europe and the existential challenge of post-COVID recovery", April 20, 2020. See https://www.brookings.edu/blog/order-from-chaos/2020/04/20/europ e-and-the-existential-challenge-of-post-covid-recovery/ (Accessed on June 25, 2020).
} 
routines and lived experiences with ethnic or nationalist content (Goode et al. 2020: 2-3). Following the constructivist turn, it is posited that everyday nationalism does not regard people as mere passive receptacles of top-down nationalist messages, but also active agents in producing, manipulating, and practicing their own version of nationalism (Goode and Stroup 2015; Fox and Van Ginderachter 2018). Although the practices of everyday nationalism are more often observed in settled times (Bonikowski 2016), the pandemic crisis provides an unsettled environment in which people perform daily nationalist responses as their everyday lives have been profoundly changed by various uncertainties.

The COVID-19 outbreak has impacted every aspect of the society, prompting a resurgence of nationalist and xenophobic sentiments among some native people. ${ }^{12}$ As the coronavirus sweeps through Europe, there have been multiple reports of incidents of racism, xenophobia, discrimination, and intolerance directed against certain national or ethnic communities linked to the COVID-19 pandemic in most European countries. It started with verbal and physical attacks targeted at Chinese nationals and those perceived to be of Chinese or Asian origin, which then expanded beyond East Asian populations to asylum seekers, refugees, immigrants, and foreigners in general. A survey conducted with 300 persons of Chinese background in The Netherlands in February 2020 showed that nearly half of respondents had experienced racist and xenophobic incidents of some kind since the outbreak of the disease. ${ }^{13}$ According to the report published by the European Union Agency for Fundamental Rights (FRA), people with Asian faces in Denmark, Italy, France, Germany, Finland, and Estonia have experienced multiple forms of xenophobia and discrimination connected with COVID-19, involving discriminatory incidents such as name-calling, inappropriate staring, being overtly distanced, and in most severe cases, physical violence. For example, in France, a young man of Chinese origin was physically attacked when leaving a night club, and a Vietnamese girl was racially insulted and punched when she was returning from school. ${ }^{14}$ Meanwhile, a string of complaints emerged about racial discrimination targeting members of the Asian diaspora in gaining access to goods and services, including denial of access to health services, education, and housing. ${ }^{15}$ Amnesty International warned that "fake news, irresponsible statements by political leaders, incomprehensible decisions by local governors and the obsessive focus of the media on coronavirus" had led to a "shameful wave of Sinophobia." 16 Besides, there is evidence of xenophobic rumors

\footnotetext{
12 For more discussions, see Chung and Li (2020); Alexandre White, 2020, "Historical linkages: epidemic threat, economic risk, and xenophobia”. Lancet (published online March 27).

13 See Avrotros (2020), 'Stinkchinees!' Dit is wat Chinese Nederlanders naar hun hoofd geslingerd krijgen sinds het uitbreken van het coronavirus", February 13, 2020.

14 See FRA, "Coronavirus Pandemic in the EU: Fundamental Rights Implications", March 20, 2020, available at https://fra.europa.eu/sites/default/files/fra_uploads/fra-2020-coronavirus-pandemic-eu-bulle tin-1_en.pdf, pp. 33-36.

15 See also the interactive Europe-wide information map created by The European Network Against Racism, available at https://www.enar-eu.org/COVID-19-impact-on-racialised-communities-interactiv e-EU-wide-map (Accessed on July 2, 2020).

16 See "Coronavirus, Amnesty International Italia: "Vergognosa ondata di sinofobia"”, available at: https ://www.amnesty.it/coronavirus-amnesty-international-italia-vergognosa-ondata-di-sinofobia/ (Accessed on September 12, 2020).
} 
blaming Muslims, Jews, Roma, and refugees for hosting the virus, even culminating in the extreme nationalists advocating for social exclusion. ${ }^{17}$ The pandemic crisis creates fear. Fear makes people more likely to develop nativist attitudes and adopt some form of "othering" in their daily interactions, providing a key ingredient for everyday nationalism to thrive.

The COVID-19 crisis further exacerbated the existing patterns of racism, nativism, and nationalism that have long been championed by right-wing populists. Narratives about crises reinforce social and pollical cleavages (Cross 2017). Nationalist politicians and radical-right parties across Europe have been opportunistic to use the outbreak to further discriminate and reiterate their calls for tougher policies on immigration and regionalization. For example, Italy's far-right politician Matteo Salvini, leader of the League Party, has erroneously linked the emergence and spread of the virus to African asylum seekers who have crossed the Mediterranean Sea to Europe and urged the hardest anti-migrant policy. ${ }^{18}$ Likewise, the Hungarian populist leader Viktor Orban was among the first to depict the coronavirus as "spreading among foreigners," declare states of emergency, ban the entry of all non-nationals, and suspend transit zone camps for asylum seekers. Far-right politicians in France, Germany, Spain, Poland, and Greece took similar steps to seize on opportunities presented by the pandemic to augment their voice and push nationalist agendas. ${ }^{19}$ In fact, these nationalist policy responses have disproportionately affected the daily life of marginalized groups and ethnic minorities, increasing their susceptibility to experiencing structural inequality. For instance, Roma minorities in Bulgaria and Slovakia were stigmatized by populist politicians for causing this pandemic and faced targeted testing and racial discrimination when lockdowns ${ }^{20}$ were implemented. According to Amnesty International's investigations, over 50,000 Roma citizens who are under compulsory quarantine in Bulgaria suffered severe food shortages and limited access to water and basic sanitation. ${ }^{21}$ As a result, the COVID-19 pandemic is no longer merely a public health crisis, but also provides a new convenient reason for the national-populists and Eurosceptics to capitalize on public fear and confusion so as to create self-other distinction and take nativist control. As Nigel Farage, leader of the far-right party in the UK, twittered, "We are all nationalists now." The anti-immigration stances and hate speeches (especially those on social media) by populist politicians will in turn contribute to a sharp increase in extremist

\footnotetext{
17 European Network Against Racism collected 191 cases between January and April 2020, available at: https://www.enar-eu.org/COVID-19-impact-on-racialised-communities-interactive-EU-wide-map (Accessed on September 12, 2020).

18 See Ciara Nugent, 2020, "Italy's Far-Right Seeks to Gain from Coronavirus Outbreak", available at https://time.com/5789666/italy-coronavirus-far-right-salvini/ (Accessed on July 2, 2020).

19 See Daniel Trilling, 2020, "Migrants aren't spreading coronavirus-but nationalists are blaming them anyway", available at https://www.theguardian.com/commentisfree/2020/feb/28/coronavirus-outbreakmigrants-blamed-italy-matteo-salvini-marine-le-pen (Accessed on July 2, 2020).

20 See Holt (2020).

21 See Amnesty International Public Statement, 17 April, 2020, available at https://www.amnesty.org/ download/Documents/EUR0121562020ENGLISH.PDF (Accessed on July 3, 2020).
} 
and nationalist attitudes among the nativist public. The convergence of nativism and populism turns into an everyday form of neo-nationalism.

\section{Coronationalism or Europeanism? A Tale of Two Causations}

When a crisis spreads, often so does nationalism too. Neo-nationalism usually emerges as a reactionary approach in times of crisis. This formula has been observed in Europe repeatedly during the past decades, as shown in the financial crisis, the Euro-zone debt crisis and the refugee crisis. Once again, this year, a new crisis of coronavirus pandemic has been accompanied by various symptoms of rising nationalism as illustrated above. Ko Colijn first used the term of Coronationalism to describe the renewed nationalism generated by the coronavirus crisis. ${ }^{22}$ However, the coronavirus crisis appears different from previous crises in some aspects. Researchers and observers hold divergent views of the long-term impact of the coronavirus crisis on nationalism in Europe.

One camp of scholars and observers argued that there will be "old answers to new problems" in a sense that far-right populists across the European continent will seize on the favorable political opportunities created by the COVID-19 crisis to push their agenda of nativism, protectionism, anti-migration, and anti-regionalism, thus fulfilling the "winning formula" of neo-nationalism. ${ }^{23}$ There are at least three mechanisms through which the coronavirus crisis can result in a surge in nationalism. First, the rampant spread of the COVID-19 virus incessantly intensifies the sense of emergency, which causes people to depend on the nation state which is responsible for providing health protection, social security, and financial assistance. Compared to regional organizations such as the EU, modern nation states can be held accountable more directly by their citizens to take much-needed responsive actions (Miller 1997), especially in handling crisis. The absence of a pan-European response to the pandemic in the early days of the outbreak has further reinforced the far-right's Eurosceptic messages and pushes nation states to turn inward. For example, about $88 \%$ of Italians felt that Europe failed to provide adequate support to the country during the crisis. ${ }^{24}$ Also feeding into EU skepticism is the chaotic border closures and the dispute over common corona debts. Second, the profound changes imposed by the public health crisis and the very real suffering caused by the coronavirus inevitably lead people to try and find scapegoats to blame, revealing societal tensions. Accordingly, nativist populists capitalize on public grievances and intensify the blame game by circulating misinformation and instigating scapegoating, even targeting those who do not deserve to have the fingers pointed at them, such as innocent immigrants

\footnotetext{
${ }^{22}$ For more details, see https://spectator.clingendael.org/nl/publicatie/coronationalisme (Accessed on June 10, 2020).

23 The term of "winning formula" was first introduced by Herbert Kitschelt in analyzing how Europe's right-wing populists achieve electoral success by incorporating authoritarianism and anti-migration policies. See Kitschelt (1997).

24 See https://www.ecfr.eu/article/commentary_whatever_it_takes_italy_and_covid_19_crisis (Accessed on July 12, 2020).
} 
and refugees. Through manufacturing "outside threats", as nationalists already did before the pandemic broke (Kaushal 2019), Europe's far right can incorporate public fear, anxiety, and confusion into their populist playbook. Third, because of the severity of the health crisis, incumbent parties and leaders often portray the fight against the coronavirus as a "war". This will cause a "rally-round-the-flag" effect $^{25}$ and increase the support for the authority of the nation states. There is evidence that government approval ratings have enjoyed obvious surges in most European countries that are the "Covid-19 epicenter" as Europeans rally behind their national leaders amid the outbreak. ${ }^{26}$ For example, there is a palpable increase in support/ approval ratings for the authorities in Italy $(+27 \%)$, the United Kingdom (5\%), Germany $(+11 \%)$, and France $(+15 \%)$. The handling of the pandemic crisis has led to the unprecedented expansion of state authority. Some populist leaders in power took steps to advance their authority domestically and resorted to illiberal means to further consolidate their authoritarian power. ${ }^{27}$ A good case in point is Hungary where extraordinary powers were granted to Prime Minister Viktor Orban to rule by decree in managing the state of emergency prompted by the coronavirus. In Poland, the populist incumbent president Andrzej Duda was just reelected into the government on July 13, with the prospect of intensified EU-Poland tensions. Consequently, populism, nativism, protectionism, Euroscepticism, and authoritarianism are mutually reinforcing each other in these countries, and jointly contribute to the resurgence of neo-nationalism. Overall, prevailing wisdom holds that the COVID-19 crisis could reopen old wounds of neo-nationalism, radicalize mainstream views, normalize populist politics, test the limits of solidarity, and even undermine the solidarity/unity of the EU.

The other camp of observers, however, believes that the coronavirus crisis could be bad news for Europe's radical right and will likely generate a counter-wave against neo-nationalism. In handling the global crisis, pro-EU politicians and parties can gain more leverage in their home countries and, at the same time, also enhance regionalization and consolidate solidarity at the European level. Additionally, there are three plausible mechanisms through which the pandemic crisis generates an anti-nationalism pushback. First, the crisis may enhance European solidarity (Koos 2019). The scale of devastation has been so vast amid the pandemic that it becomes increasingly obvious to people that only inter-dependency and cooperation can provide the most promising solution in combating the virus over the long term, even though they may have benefited from short-term isolation. This can therefore lead to a greater sense of solidarity. Although there is a clear retreat from globalization as citizens turned back to national governments for protection in the early months of the outbreak, the suffering caused by the disjointed cross-national efforts, fragmented supply chains, and widespread travel bans also reiterated the importance

\footnotetext{
${ }^{25}$ For related research, see Newman and Forcehimes (2010); Hetherington and Nelson (2003).

26 See the polling data collected by Europe Elects, available https://europeelects.eu/2020/04/01/coron avirus-european-leaders-enjoy-surging-approval-ratings-amid-crisis/ (Accessed on July 12, 2020).

27 See https://www.nytimes.com/2020/03/30/world/europe/coronavirus-governments-power.html (Accessed on July 12, 2020).
} 
of regional cooperation. This provides the EU a rare chance to reestablish its reputation, legitimacy, and solidarity by bringing member states together in fighting a common crisis. As the President of the European Commission called for in a speech to the European Parliament: "Let us do the right thing together - with one big heart, not 27 small ones." ${ }^{28}$ Second, the pandemic crisis has revealed the significant role of expertise, science, rationality, informed decisions, established institutions, coordinated policies, and professional governance. All of these expose the limits of farright populism which has long been committed to promulgating anti-establishment movements, spreading misinformation, and downplaying science. Therefore, in many of the European countries, the percent of people who think the government is handling the issue of coronavirus very and somewhat well remains high. ${ }^{29}$ In contrast, a gradual stagnation and decline in backing of far-right parties and populist figures have occurred in the past months. Opinion polls conducted by the Europe Elects reveal that far-right parties in Italy, Spain, and Germany have lost ground since the outbreak. ${ }^{30}$ In addition, there is evidence that immigrant workers in various sectors have played an indispensable role in containing the pandemic. As appointed out by political scientists at the European University Institute, although Europe's radical right may achieve what they have long called for, including closed borders and suspended free movement, these situations could, ironically, "rob Europe's radical-right parties of their anti-immigration political niche." ${ }^{31}$ Third, to recover from the crisis, the economic and market issues will largely dominate the political agenda of most European countries in the post-coronavirus era. Not only will this make the immigration issue less salient as a political concern for years to come, but it may also highlight the increased need for a European-wide single market and free movement. Additionally, there are signs that pro-EU national leaders will be able to use their growing support and trust at home to further promote long-awaited EU policy initiatives to reduce future vulnerabilities. The public health crisis has revealed the urgency of deepening reforms in various issue areas, including healthcare, industrial policy, labor markets, welfare redistribution, and economic relief. The EU can perform as the driver of collective changes in these fields by creating a more integrated and cohesive regionalization. Overall, based on the above observations, many researchers insist that the COVID-19 crisis has fomented an unprecedented political opportunity for the EU to expand solidarity (see Fig. 1) ) $^{32}$ and for the mainstreams to contain neo-nationalism.

\footnotetext{
${ }^{28}$ See the European Solidarity Tracker, available at https://www.ecfr.eu/solidaritytracker (Accessed September July 13, 2020).

${ }^{29}$ See the survey data by YouGov, available at https://yougov.co.uk/topics/international/articles-repor ts/2020/03/17/perception-government-handling-covid-19 (Accessed July 13, 2020).

${ }^{30}$ See the survey data by Europe Elects, available at: https://www.euronews.com/2020/05/21/coronaviru s-why-did-european-leaders-approval-ratings-rise-during-lockdown.

${ }^{31}$ See James Dennison and Andrew Geddes, 2020, "Why coronavirus is likely to be bad news for Europe's radical right", available at https://cadmus.eui.eu/handle/1814/66970 (Accessed July 13, 2020).

${ }^{32}$ This illustration is based the solidarity data collected by the European Council on Foreign Relations (ECFR). According to the data description, "“EU" indicates items that concern the institutions of the union, whereas "EU27" is used for items that address the community of EU member states." See https:// www.ecfr.eu/solidaritytracker (Accessed September 17, 2020). I thank the ECFR for generously sharing the original dataset.
} 
As seen from above, the COVID-19 crisis presents both European nationalists and liberalists an opportunity to appeal to the vast number of their nationals. On one hand, it gives a clear advantage to nativist populism and leads to a larger role of nation state. On the other hand, it makes the shift towards established mainstream politics and pushes for supranational solidarity in the globalized, unpredictable world. Therefore, the causal relation from crisis to nationalism is not a linear, oneway process in which it is impossible to change course or reverse trend. As illustrated in Fig. 2, the rise and fall of neo-nationalism in Europe will not only be contingent on how long the COVID-19 pandemic and the short-term responses to it, but also largely conditioned by the existing political ecology that predates the pandemic, and more importantly, will finally be determined by the long-term agenda the EU and its member states adopt in recovering the economy and reforming the system in the post-pandemic era.

More recently, the European Union has undertaken some positive moves to rebuild regional unity and cooperation in combating the spread of the virus and reopening the economy. This will help constrain the potential rise of nationalism. For example, the EU initiated multiple monetary plans (including a $€ 750$ billion fiscal stimulus) to support the Member States to tackle the detrimental economic consequences, proposed a common EU approach to lifting travel restrictions, increased research program budget for researchers to find a vaccine, and provided resources to prevent coronavirus-related disinformation. ${ }^{33}$ Indeed, it took some time for the EU to catch up with what the nation states have done on their own, but the regional organization has eventually stepped up and put forward a number of radical measures to mitigate the socio-economic impacts of COVID-19. The European Union has demonstrated its political resilience after going through more than a decade of incessant crises, including the financial crisis, the Euro-zone debt crisis, the refugee crisis, Brexit, and now the pandemic crisis. A recent pan-European survey carried out by European Council on Foreign Relations (ECFR) shows strong support for greater EU-level cooperation amid the pandemic crisis, with most respondents in Portugal (91\%), Spain (80\%), and Italy (77\%), the hardest-hit countries, believing in the value of having more collective European action (see Fig. 3). ${ }^{34}$ Meanwhile, a preliminary analysis of the media data from GDELT (Global Data of Event, Language and Tone $)^{35}$ also reveals that the average positive tone towards the EU in the media of Spain and Italy is on a moderate rise in the early months of the COVID-19 pandemic.

\footnotetext{
33 For a list of EU responses to the COVID-19 pandemic, see https://epthinktank.eu/2020/03/20/covid -19-novel-coronavirus-outbreak-in-europe-and-the-eu-response/ (Accessed on July 13, 2020).

34 The poll was conducted with more than 11,000 citizens in nine countries across Europe (including Bulgaria, Denmark, France, Germany, Italy, Poland, Portugal, Spain, and Sweden), covering more than two-thirds of the EU's population and GDP. For more details, see Ivan Krastev and Mark Leonard, "Europe's pandemic politics: How the virus has changed the public's worldview", June 24, 2020.

35 GDELT database is the world's largest open database of political information derived from various social media, portals, online forums, and Internet news, covering more than 100 countries in 65 languages around the world.
} 


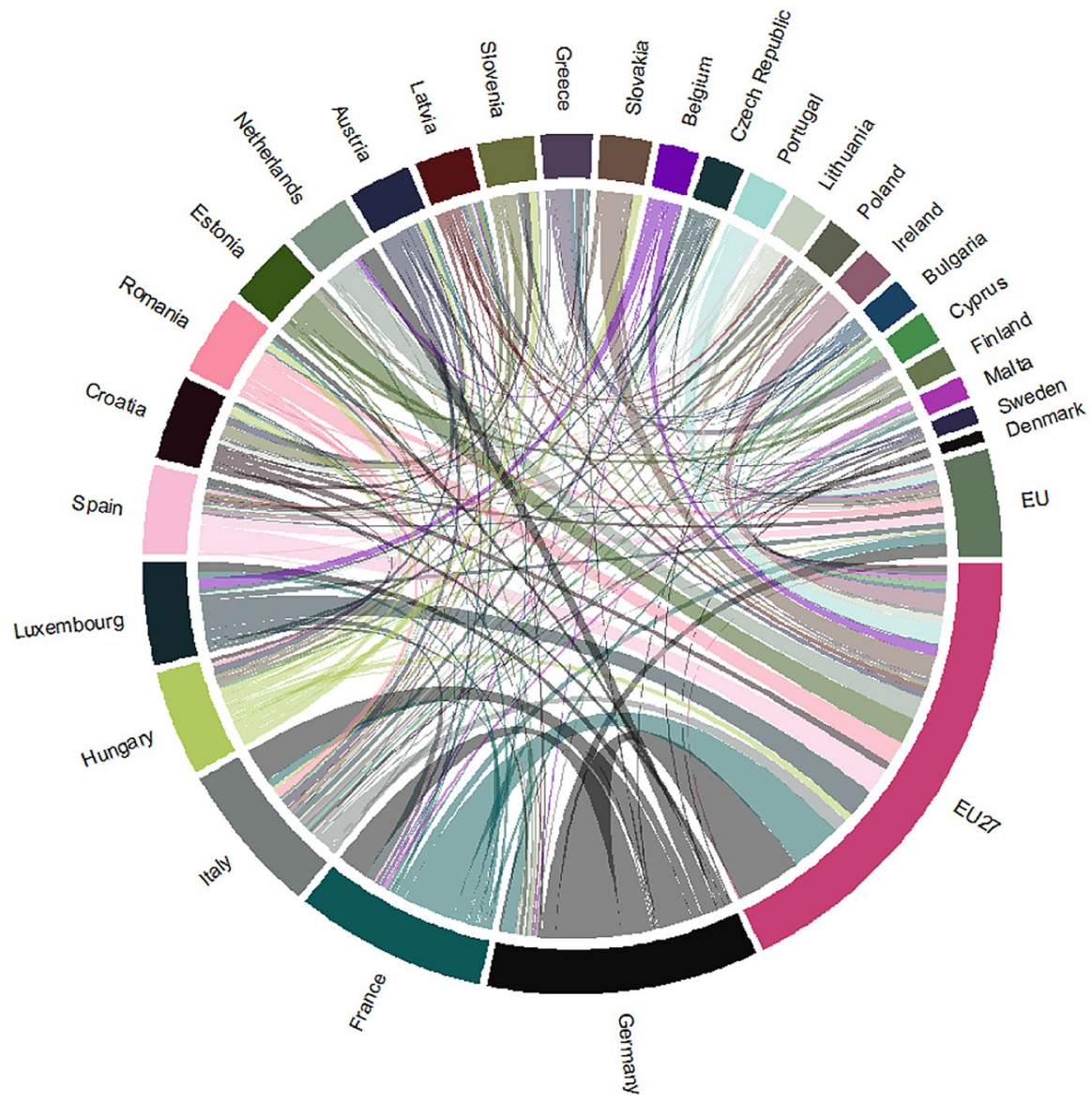

Fig. 1 The expression of solidarity among the EU member states and the EU during the coronavirus pandemic

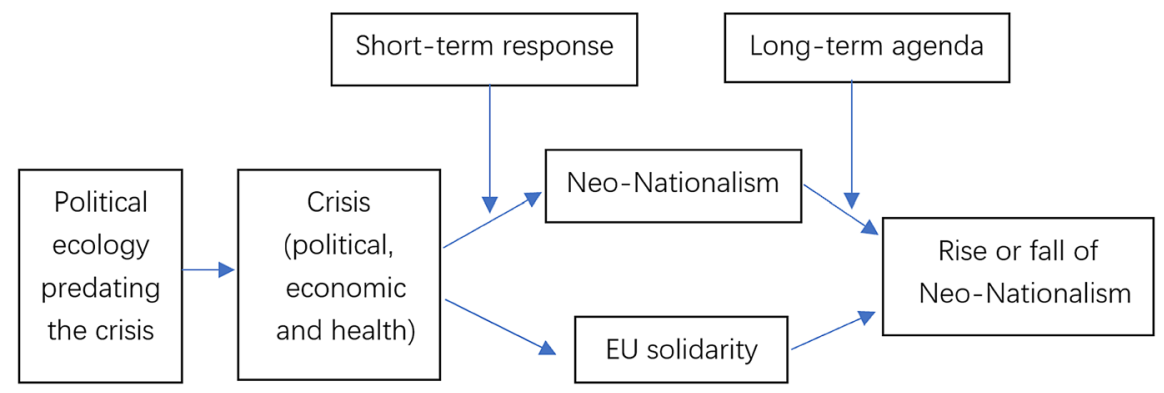

Fig. 2 The causal links from crisis to neo-nationalism 


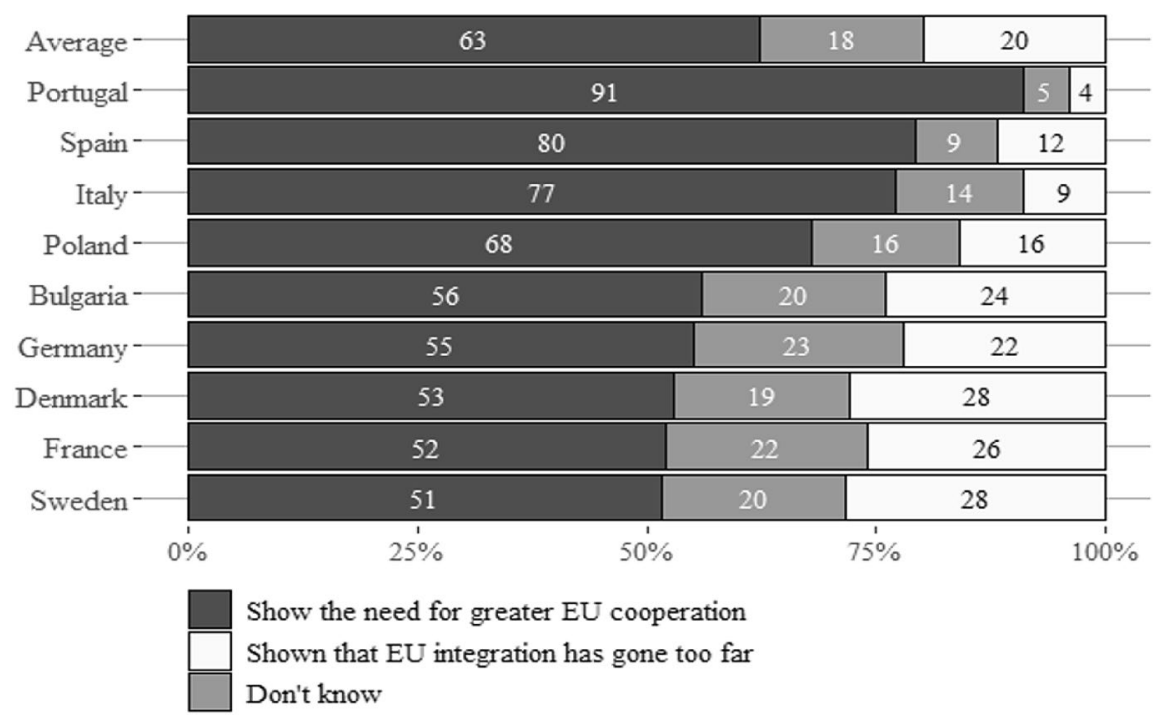

Fig. 3 How coronavirus has changed people's attitudes towards the EU

European countries are still struggling to cope with the political effects of the pandemic crisis. There have been a lot of political differences within Europe, which can be intensified by nationalist sentiments and actions amid the crisis. Also, the EU could still be trapped in a status quote without decisively resolving a number of institutional and economic challenges, even though the pandemic crisis management urges them to do so. As illustrated by the causal links in Fig. 2, if the EU cannot set and fulfill a long-term agenda in addressing various fundamental internal challenges within the time window granted by the pandemic crisis, it is then highly likely to witness a resurgence of post-pandemic neo-nationalism.

\section{Conclusion}

Will nationalism thrive in times of crisis? Studies of comparative politics have shown long-lasting interest in exploring the causal linkage between crises (a typical form of critical juncture) to nationalism. The COVID-19 pandemic constitutes what the United Nations labeled "the largest global public health crisis in a century". Such a devastating crisis would likely result in a new wave of neo-nationalism in Europe, something that has already assailed the continent during the past decade of crises such as the Euro-zone debt crisis and immigrant crisis. Not surprisingly, the early days of the global pandemic crisis have witnessed some hybrid of medical nationalism, economic nationalism, and everyday nationalism, as illustrated in this article. Thus, it appears evident that the pandemic crisis has created new cleavages in the society and pushed nationals to pin blame on outsiders, take self-protectionist 
actions, adopt nativist narratives, and resort to anti-globalization movements, which provide fertile ground to grow neo-nationalism in the short term.

However, in the long run, it remains to be seen whether neo-nationalism will get a boost in Europe because of the coronavirus crisis. There appear to be divergent mechanisms through which both nationalists and liberalists can capitalize on the political opportunities in the pandemic. The causation from crisis to nationalism is not a linear, one-way process. The development of neo-nationalism in Europe will be largely contingent on the long-term agenda that the EU and the member states adopt in handling the complexity of domestic and regional challenges in the postpandemic era. The crisis can also be well managed to strengthen solidarity, increase interdependence, and enhance the authority, adaptability, and resilience of the supranational union (Koos 2019; Barbier-Gauchard et al. 2020). It is still too early to claim that "the coronavirus crisis has led to increased nationalism in Europe". Therefore, instead of exploring the causal relation from crisis to nationalism, more-nuanced questions can be asked concerning the conditions under which and mechanisms through which a specific type of crisis is more/less likely to provoke nationalism.

\section{Compliance with ethical standards}

Conflict of interest The author states that there is no conflict of interest.

\section{References}

Anderson, Benedict. 1991. Imagined Communities: Reflections on the Origin and Spread of Nationalism, revised ed. London: Verso.

Barbier-Gauchard, Amélie, Meixing Dai, Claire Mainguy, Jamel Saadaoui, Moïse Sidiropoulos, Isabelle Terraz, and Jamel Trabelsi. 2020. Towards a More Resilient European Union after the COVID-19 Crisis. BETA Working Paper 2020-33. SSRN: https://ssrn.com/abstract=3641306. Accessed 12 July 2020.

Bergmann, Eirikur. 2020. Neo-Nationalism: The Rise of Nativist Populism. London: Palgrave Macmillan. Bonikowski, Bart. 2016. Nationalism in settled times. Annual Review of Sociology 42 (1): 427-449.

Charney, Evan. 2003. Identity and liberal nationalism. American Political Science Review 97: 295-310.

Chung, Yat-Nork, and Minnie Ming Li. 2020. Anti-Chinese sentiment during the 2019-nCoV outbreak. Lancet 395: 686-687.

Cross, Mai'a K.Davis. 2017. The Politics of Crisis in Europe. Cambridge: Cambridge University Press.

DeSoucey, Michaela. 2010. Gastronationalism: Food traditions and authenticity politics in the European Union. American Sociological Review 75 (3): 432-455.

Fabre, Thierry, and Paul Sant-Cassia (eds.). 2007. Between Europe and the Mediterranean: The Challenges and the Fears. London: Palgrave Macmillan.

Fox, Jon E., and Maarten Van Ginderachter. 2018. Introduction: Everyday nationalism's evidence problem. Nations and Nationalism 24 (3): 546-552.

Gellner, Ernest. 1983. Nations and Nationalism. Oxford: Blackwell.

Gerring, John. 2010. Causal mechanisms: Yes, but.... Comparative Political Studies 44 (11): 1499-1526.

Gilpin, Robert. 1987. The Political Economy of International Relations. Princeton: Princeton University Press.

Gilbert, Paul. 1998. The Philosophy of Nationalism. Boulder, CO: Westview Press.

Gledhill, John. 2005. The power of ethnic nationalism: Foucault's bio-power and the development of ethnic nationalism in Eastern Europe. National Identities 7 (4): 347-368. 
Gingrich, Andre, and Marcus Banks (eds.). 2006. Neo-nationalism in Europe and beyond: Perspectives from social anthropology. New York: Berghahn Books.

Givens, Terri E. 2005. Voting Radical Right in Western Europe. Cambridge: Cambridge University Press.

Goode, J.Paul, and David R. Stroup. 2015. Everyday nationalism: Constructivism for the masses. Social Science Quarterly 96 (3): 717-739.

Goode, J.Paul, David R. Stroup, and Elizaveta Gaufman. 2020. Everyday nationalism in unsettled times. In search of normality during pandemic. Nationalities Papers 40: 1-25.

Hechter, Michael. 2000. Containing Nationalism. Oxford: Oxford University Press.

Hetherington, Marc J., and Michael Nelson. 2003. Anatomy of a rally effect: George W. Bush and the war on terrorism. PS: Political Science and Politics 36 (1): 37-42.

Holt, Ed. 2020. COVID-19 lockdown of Roma settlements in Slovakia. Lancet Infect Dis 20 (6): 659.

Ichijo, Atsuko, and Ronald Ranta. 2016. Food, National Identity and Nationalism: From Everyday to Global Politics. London: Palgrave Macmillan.

Ignazi, Piero. 2003. Extreme Right Parties in Western Europe. Oxford: Oxford University Press.

Kaushal, Neeraj. 2019. Blaming Immigrants: Nationalism and the Economics of Global Movement. New York: Columbia University Press.

Kitschelt, Herbert. 1997. The Radical Right in Western Europe: A Comparative Analysis. Ann Arbor: University of Michigan Press.

Koos, Sebastian. 2019. Crises and the reconfiguration of solidarities in Europe-Origins, scope, variations. European Societies 21 (5): 629-648.

McAdam, Doug, Sidney Tarrow, and Charles Tilly. 2008. Methods for measuring mechanisms of contention. Qualitative Sociology 31 (3): 307-331.

Miller, David. 1997. On Nationality. Oxford: Oxford University Press.

Miller, David. 2008. Nationalism. In The Oxford Handbook of Political Theory, ed. John Dryzek, Bonnie Honing, and Anne Phillips, 529-545. Oxford: Oxford University Press.

Mudde, Cas. 2000. The Ideology of the Extreme Right. New York: Manchester University Press.

Mudde, Cas. 2007. Populist Radical Right Parties in Europe. Cambridge: Cambridge University Press.

Mudde, Cas. 2016. On Extremism and Democracy in Europe. London: Routledge.

Newman, Brian, and Andrew Forcehimes. 2010. "Rally round the flag" events for presidential approval research. Electoral Studies 29 (1): 144-154.

Norris, Pippa. 2005. Radical Right: Voters and Parties in the Electoral Market. New York: Cambridge University Press.

Norris, Pippa, and Ronald Inglehart. 2019. Cultural Backlash and the Rise of Populism: Trump, Brexit, and Authoritarian Populism. New York: Cambridge University Press.

Pryke, Sam. 2012. Economic nationalism: Theory, history and prospects. Global Policy 3 (3): 281-291.

Sartori, Giovanni. 1966. European political parties: The case of polarized pluralism. In Political Parties and Political Development, ed. LaPalombara and M. Weiner, 137-176. Princeton: Princeton University Press.

Tamir, Yael. 1993. Liberal Nationalism. Princeton: Princeton University Press.

Tilly, Charles. 2001. Mechanisms in political processes. Annual Review of Political Science 4: 21-41.

Zhongyuan Wang is assistant professor and research fellow at the Fudan Institute for Advanced Study in Social Sciences (IAS-Fudan). He received his doctoral degree at Leiden University and had ever worked as a lecturer in the Program of International Studies at Leiden University. His research interests include comparative political institutions, election studies, political representation, local politics and governance, and governmental big data. His work has appeared in European Political Science, Journal of Contemporary China, Asian Survey, Journal of Chinese Political Science, and China Information. He currently serves as the Deputy Director of Contemporary China Research Center at Fudan University. 